\title{
Differential diagnosis of the granulomatous appendicitis: Retrospective analysis of 16 cases
}

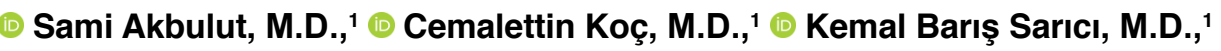

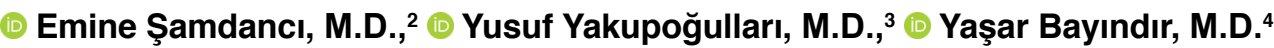

\author{
${ }^{1}$ Department of General Surgery, İnönü University Faculty of Medicine, Malatya-Turkey \\ ${ }^{2}$ Department of Pathology, Inönü University Faculty of Medicine, Malatya-Turkey \\ ${ }^{3}$ Department of Medical Microbiology, Inönü University Faculty of Medicine, Malatya-Turkey \\ ${ }^{4}$ Department of Infectious Disease, İnönü University Faculty of Medicine, Malatya-Turkey
}

\begin{abstract}
BACKGROUND: This study aims to present the usability of real-time polymerase chain reaction (PCR) and interferon-gamma release assay (IGRA) in the differential diagnosis of granulomatous appendicitis (GAp), especially in areas where tuberculosis (TB) is endemic.

METHODS: Sixteen patients underwent appendectomy with presumed diagnosis of acute appendicitis were retrospectively analyzed for histopathological diagnosis of GAp. Real-time PCR method was used to show the whether presence of DNA of the tubercle bacilli in paraffin-embedded tissue blocks. IGRA test was used to investigate whether tubercle bacilli- specific interferon gamma was present in peripheral blood.
\end{abstract}

RESULTS: Sixteen patients (male: 10 female: 6) aged between 21 and 82 years were included in this study. All patients had acute appendicitis and three of them also had appendiceal perforation. Histopathologically, necrotizing granulomatous inflammation was detected in all appendectomy specimens. Acid-fast bacilli were not detected in any of the pathology slides stained with Ehrlich-Ziehl-Neelsen . Real-time PCR was studied in paraffin-embedded tissue blocks of all patients with GAp, but the TB bacilli DNA was amplified in only three patients. IGRA test was studied in peripheral blood samples of 12 patients with GAp and results were as follows: negative $(n=9)$, positive $(n=2)$ and indeterminate $(n=1)$.

CONCLUSION: We believe that the use of anamnesis, histopathological findings, tissue PCR, blood IGRA and clinical findings together are important for differential diagnosis of GAp, especially where TB is endemic. We also suggest that all appendectomy specimens should be sent to the laboratory for histopathological evaluation even if specimens appear macroscopically normal.

Keywords: Acute appendictis; granulomatous appendicitis; interferon-gamma release assay; perforated appendicitis; polymerase chain reaction.

\section{INTRODUCTION}

Acute appendicitis (AAP) is one of the most common causes of admission to the emergency units due to abdominal pain and appendectomy is one of the most frequent surgical procedure worldwide. ${ }^{[1,2]}$ The most common triggering factor for AAp is fecalith in adults and lymphoid hyperplasia in children. ${ }^{[1,2]}$ Apart from these known trigger factors of AAp, one of the most emphasized causes is granulomatous inflammation that arises from Crohn's disease and gastrointestinal tuberculosis $(\mathrm{TB}) .^{[1,2]}$

Granulomatous appendicitis (GAp) is a disease characterized by chronic granulomatous inflammation in the wall of the appendix vermiformis and according to the literature, the incidence of GAp in appendectomy specimens varies be-

Cite this article as: Akbulut S, Koç C, Sarıcı KB, Şamdancı E, Yakupoğulları Y, Bayındır Y. Differential diagnosis of the granulomatous appendicitis: Retrospective analysis of 16 cases. Ulus Travma Acil Cerrahi Derg 2021;27:214-221.

Address for correspondence: Sami Akbulut, M.D.

İnönü Üniversitesi Tıp Fakültesi, Genel Cerrahi Anabilim Dalı, Malatya, Turkey

Tel: +90 422 - 34I 0660 E-mail: akbulutsami@gmail.com

Ulus Travma Acil Cerrahi Derg 2021;27(2):2I4-22I DOI: 10.14744/tjtes.2020.98582 Submitted: 26.02.2020 Accepted: II.04.2020

Copyright 2021 Turkish Association of Trauma and Emergency Surgery 
tween $0.1 \%$ and $2 \% .^{[3-5]}$ Although many benign or malignant diseases may cause GAp, Crohn's disease, Yersinia spp., and Mycobacterium spp. are the most common specific causes of GAp. ${ }^{[3]}$ However, in majority of patients with GAp, a specific factor that may cause granulomatous inflammation cannot be identified, which is called idiopathic GAp. ${ }^{[3,6,7]}$ TB is one of the most important causes of GAp in endemic regions, such as some areas of the Turkey. Therefore, TB is among the most emphasized diseases in the differential diagnosis of GAp. Most of the microbial agents or foreign bodies that cause GAp can be easily identified on histopathological examination of the appendectomy specimen. However, it is difficult to directly detect the tubercle bacilli on histopathological examination of the specimen in most of patients and necrotizing granulomatous inflammation suggesting $T B$ is usually seen. To differential diagnosis of GAp detected in patients who living in areas where TB is endemic, or patients who have risk factor for TB, the following parameters should be evaluated together: physical examination, personal or familial history, biochemical analysis, radiological instruments, molecular biological techniques and histopathological findings. ${ }^{[8]}$ In the present study, we aimed to share the usability of the tissue real time polymerase chain reaction (PCR) and blood interferon-gamma release assay (IGRA) methods in the differential diagnosis of GAp.

\section{MATERIALS AND METHODS}

Histopathological examination record of 2726 patients who underwent appendectomy with presumed diagnosis of AAp in Department of Surgery, İnönü University Faculty of Medicine between January 1999 and April 2019 were retrospectively evaluated. Demographic, clinical and biochemical features of 16 patients who histopathological examination findings were compatible with GAp were evaluated in detail. The microscope slides were re-examined by a pathologist experienced in gastrointestinal system pathology and the definitive diagnosis of GAp was confirmed. To investigate whether or not DNA material of tubercle bacilli was found in appendectomy specimen, tissue real time PCR technology was used to detect tubercle bacillus by nucleic acid amplification method in paraffin-embedded tissue blocks. In addition, patients whose telephone numbers were up-to-date in the hospital patient information system were called to check out the outpatient clinic. Thirteen patients who agreed to come to the outpatient clinic were evaluated using the following parameters for pulmonary and/or extrapulmonary tuberculosis: anamnesis (personal and familial), physical examination, chest x-ray radiography, white blood cell count, erythrocyte sedimentation rate (ESR; $\mathrm{mm}$ ) TB skin test (PPD test; $\mathrm{mm}$ ) and whole-blood IGRA After the approval of the İnönü University institutional review board for non-interventional studies (Approval No: 2019/9-27), the patients' files were retrospectively examined. Written and verbal informed consent was obtained from patients who came to the outpatient clinic control for IGRA analysis.
DNA Extraction from Paraffin-Embedded Tissue Specimens

Tissue sections at 5-10 $\mu \mathrm{m}$ thickness were obtained from the formalin-fixed paraffin-embedded (FFPE) tissue sample with a microtome device, and placed to a sterile micro-centrifuge tube. Deparaffinisation was performed according to a modified xylene method as fellows: I ml xylene was added to each micro-centrifuge tube consisting FFPE tissue sections and vortexed for 10 seconds. After complete lyses of paraffin, the tubes were centrifuged at $13.000 \mathrm{~g}$ for $10 \mathrm{~min}$, and a tissue pellet was obtained. The pellet was washed two times with absolute ethanol to remove the remaining xylene, supernatant was aspirated, and then the tubes were kept in biosafety cabinet at lid-open position for $10 \mathrm{~min}$ to evaporate the alcohol. In the next step, DNA extraction was done with QIAamp DNA FFPE Tissue kit (Qiagen, Germany) according to the manufacturer's instructions.

\section{TB Detection with HyBeacon Technology-Based Real-Time PCR Method}

To amplify the TB DNA in the samples, a commercial FluoroType MTB (Hain Lifescience, Germany) real-time PCR system targeting IS 6110 gene regions of the organism was used. The procedures were performed according to the manufacturer's instructions. This system carried out melting-curve analysis with a software (Fluoro-Software, Germany) according to positive and negative amplification controls, and gave results as "no MTB complex DNA detected" or "MTB complex DNA detected".

\section{Interferon-Gamma (IFN- $\gamma)$ Release Assay (IGRA)}

Interferon-gamma response of the patients to $M$. Tuberculosis was measured with QuantiFERON-TB GOLD Test (Cellestis, Australia), a US Food and Drug Administration (FDA)-approved and Centers for Disease Control and Prevention (CDC)-recommended test to diagnose latent and active TB. ${ }^{[9]}$ In this test, three specific antigens of M. tuberculosis, including ESAT-6, CFPI 0 and TB7.7, were used to stimulate the patient's $T$ cells to produce IFN- $\gamma$ and released IFN- $\gamma$ was measured with Enzyme-Linked Immunosorbent Assay (ELISA). Three $\mathrm{ml}$ peripheral blood samples were collected from the patients and divided into three test tubes ( $1 \mathrm{ml}$ per tube). The tubes were gently shaken for five seconds and incubated at $37^{\circ} \mathrm{C}$ for 16-24 hours. The plasma in the tubes was separated by centrifugation at $2500 \mathrm{~g}$ for five min then subjected to ELI$\mathrm{SA}$ analysis. The measured IFN- $\gamma$ concentration in the plasma samples were expressed as $\mathrm{IU} / \mathrm{ml}$, and the results were given as "positive", "negative" or "intermediate" by the device.

\section{Histopathologic Evaluation}

The appendix vermiformis materials fixed in 10\% formalin solution underwent routine tissue follow-up. After routine tissue preparation, paraffin-embedded tissues were sliced to 
4-micron thickness and stained with and examined under light microscope. The microscopic examination of the slides revealed different sized granulomas structures, including caseous necrosis. To show specific microorganism (e.g., tubercle bacilli and fungus), 4-micron thick sections were stained with Ehrlich-Ziehl-Neelsen and Periodic Acid-Schiff stains. The histopathological findings of the patients with no specific microorganism were reported as GAp (Fig. I and 2).

\section{Statistical Analysis}

Statistical analyses were performed using Statistical Package for Social Sciences (SPSS) v25.0 (IBM Corp., Armonk, NY, USA). The continuous variables were expressed as mean \pm standard deviation, median, and range. The categorical variables were reported as number and percentage. The Mann-Whitney $U$ test was used to compare differences in continuous variables.

\section{RESULTS}

According to histopathological examination report, AAp was detected in $2113(77.5 \%)$ of 2726 patients who underwent appendectomy with a presumed diagnosis of AAp in the above-mentioned date range. Demographic and clinical parameters of 16 patients with GAp ( 10 male and 6 female) aged from 21 to 82 years (median: 30.5$)$ were analyzed retrospectively. While the ages of male patients ranged from 22 to 82 years (median: 30.5 ), the ages of female patients ranged from 21 to 53 years (median: 30.5). All patients were admitted to the emergency unit with a preliminary diagnosis of AAp and all underwent appendectomy using Mc Burney incision. Surgical findings revealed that $13(81.2 \%)$ patients had non-perforated AAp, and three (18.8\%) patients had perforated AAp. While the length of appendix vermiformis ranged from 45 to $105 \mathrm{~mm}$ (median: $72.5 \mathrm{~mm}$ ), its diameters ranged from $4 \mathrm{~mm}$ to $35 \mathrm{~mm}$ (median: $9 \mathrm{~mm}$ ). No statistically significant difference was found between male and female patients in terms of age $(p=0.635)$, appendiceal perforation $(p=0.5 \mid 8)$, length $(p=0.7 \mid 3)$ and diameter $(p=0.792)$ of the appendix vermiformis. According to the anamnesis data obtained from the files, none of the patients had any clinical findings suggesting TB in the preoperative period. Similarly, none of the patients had a familial history of TB. Of the 16 patients included in this study, only three patients were admitted to the outpatient clinic postoperatively and further investigation was performed for differential diagnosis of GAp. Twelve patients were contacted during the preparation of this study, and the peripheral blood sample was taken for the IGRA test. No communication was made with the remaining four patients, one of the patient died early in the early postoperative period.

While histopathological examination revealed granulomatous inflammation, Ehrlich-Ziehl-Neelsen staining for acid-fast bacilli (AFB) was negative for all patients. PPD $(n=13)$ and ESR values $(n=12)$ were obtained and median values of PPD and ESR rate were measured as $4 \mathrm{~mm}$ (min-max: $\mathrm{I}-\mathrm{IO}$ ) and 10 mm (min-max: 2-44), respectively. Real-time PCR was used to isolate the TB bacilli DNA from paraffin-embedded tissue blocks, but DNA was isolated in only three (18.8\%) patients' tissue blocks. Although the attempt to measure IFN produced against TB bacilli in the peripheral blood of 12 patients using the IGRA test, IFN was detected in only two (I2.5\%) patient and this result was reported as positive. In another patient, the IGRA test was repeated twice, but the test result was reported as indeterminate. To summarize, while the IGRA test was negative in three patients with positive PCR, PCR was negative in three patients with IGRA positive/ indeterminate.

We aimed to summarize two of the patients presented in this study. First, a 37-year-old female patient underwent appendectomy and drainage with a preliminary diagnosis of perforated appendicitis. A few days after the surgery, the patient
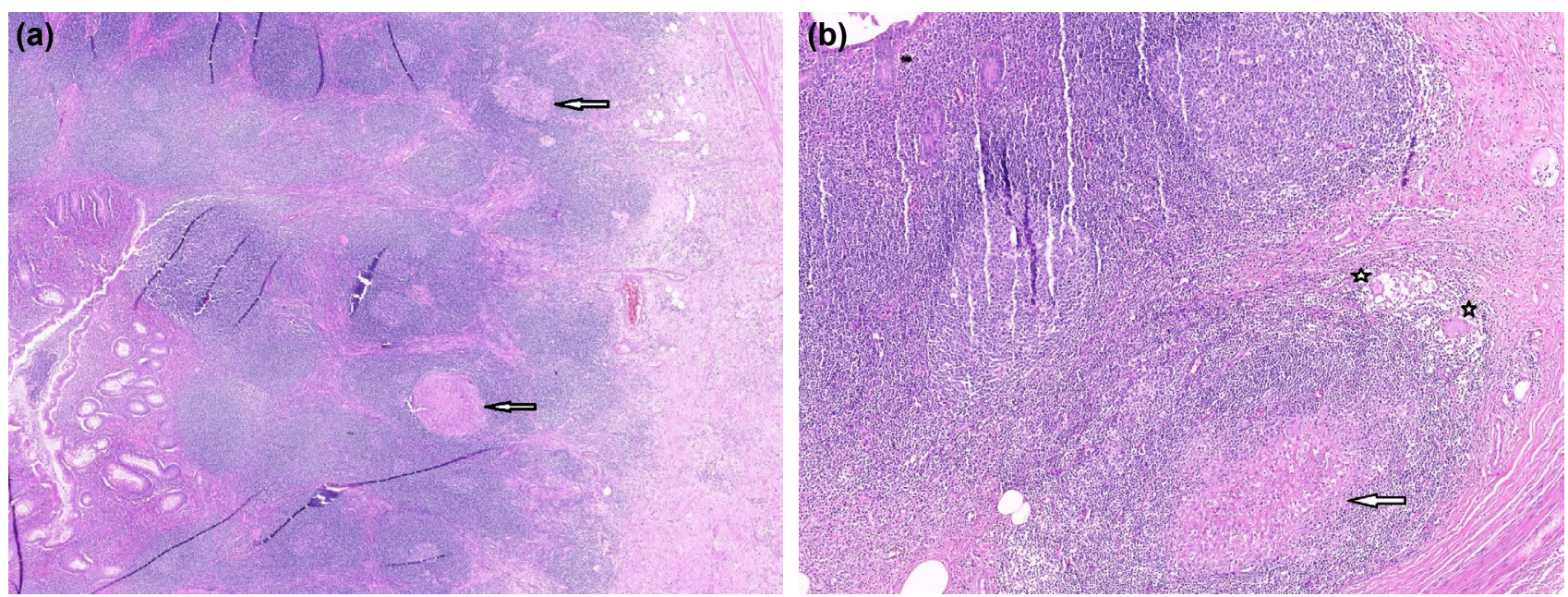

Figure 1. (a) Granulomas with caseating necrosis (arrows) in the submucosal area of appendix vermiformis (HE x1). (b) Granuloma (arrow) with giant cells (stars) (HE x5). 

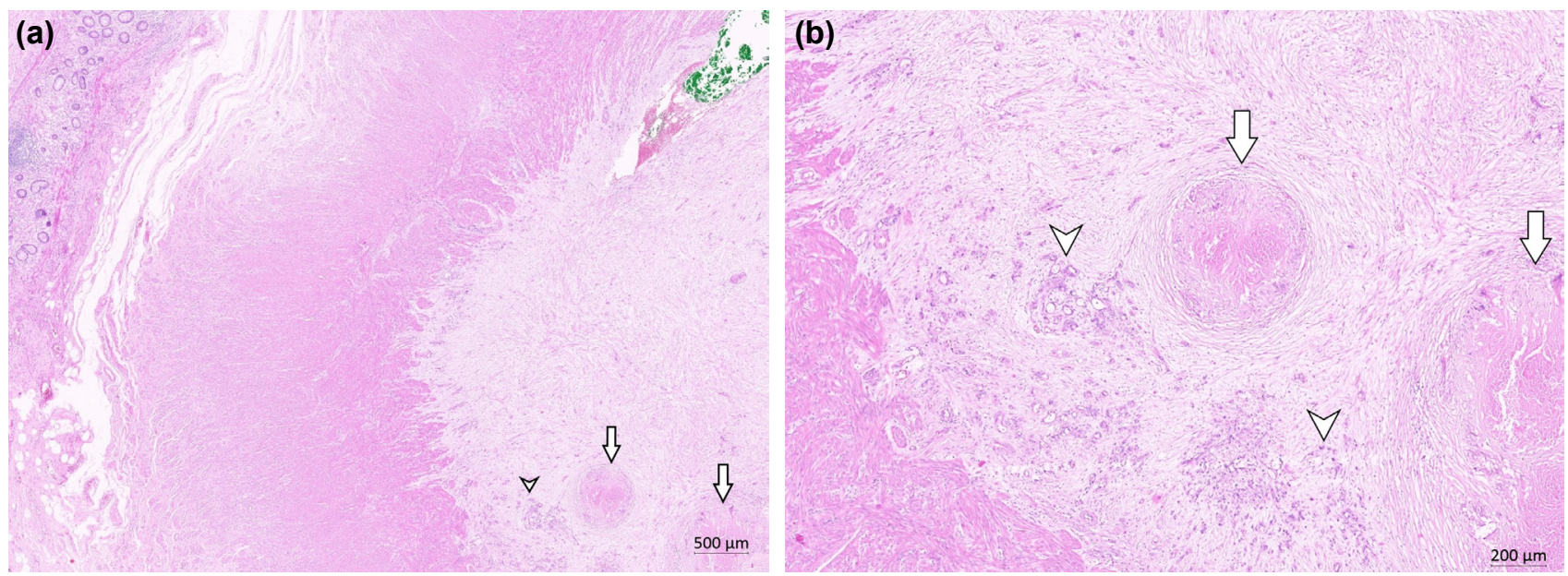

Figure 2. Necrotising granulomas (arrows) (a) and tumor cells (arrow heads) (HE x10) (b) in the appendix wall (HE x25).

re-admitted to our clinic because of purulent discharge from the incision site. As a result of the investigations performed by gastroenterologists, Crohn's disease was diagnosed and infliximab treatment was initiated. The patient is still receiving infliximab at 60 months postoperatively. Second, an 82-yearold male patient underwent subtotal gastrectomy for gastric adenocancer one year ago. The patient was treated with adjuvant chemotherapy and was admitted to the emergency department due to right lower quadrant pain. The patient underwent surgery with a preliminary diagnosis of AAp. After an appendectomy, the patient was followed up again by medical oncology. Histopathological examination revealed that necrotizing granulomatous inflammation and serosal metastatic tumor infiltration (Fig. 2). Although the diagnosis of extrapulmonary TB was clinically confirmed, antitubercular therapy could not be initiated because the patient died in the early postoperative period.

Follow-up data of 14 patients were obtained. During the one to 186 months (median: 65 months) follow-up periods, none of the patients developed clinical signs or symptoms that were compatible with TB or Crohn's disease except one patient who was diagnosed with Crohn's disease in postoperative early term. Demographic and clinical data of the 16 patients with GAp are summarized in Table I.

\section{DISCUSSION}

GAp that characterized by chronic granulomatous inflammation was first described in 1953 by Meyerding and Bertram. ${ }^{[4,10]}$ The authors stated that chronic nonspecific appendicular granulomas were similar to Crohn's disease, that no involvement of adjacent intestinal segments, and that these findings were consistent with isolated appendiceal Crohn's disease..$^{[10]}$ The authors also stated that they exclude gastrointestinal TB by clinicopathological investigations before the definitive diagnosis of isolated appendiceal Crohn's disease. ${ }^{\left[{ }^{[10]}\right.}$ Since then, more than two hundred articles related to GAp have been published in the literature. ${ }^{\left[{ }^{I I}\right]}$
GAp is a rare entity, and it has been detected in approximately $0.1-2 \%$ of all appendectomy specimens obtained from patients with AAp. ${ }^{[4,6,7,11]}$ While the incidence of GAp in western countries ranges from $0.14 \%$ to $0.30 \%$, the incidence in developing countries ranges from $1.3 \%$ to $2.3 \%\left[{ }^{[6,11]}\right.$ In our study, when all appendectomy specimens that obtained from patients underwent a presumed diagnosis of AAp were considered, the prevalence of GAp was $0.59 \%$. However, the actual prevalence of GAp was calculated as $0.75 \%$ based on histopathological proven AAp cases, which was consistent with the literature.

GAp can be classified in different ways based on the underlying causes, histopathological features, and morphological structure. ${ }^{[4]} \mathrm{GAp}$ can be divided into primary (idiopathic) and secondary GAp by considering the underlying causes. Primary GAp is defined as no reason to explain the granulomatous inflammation. Secondary GAp, the most common form of GAp, is defined as the presence of specific causes for the granulomatous inflammation. ${ }^{[4]}$

Secondary GAp is divided into non-infectious (38\%) and infectious $(62 \%)$ GAp by considering the triggering factors that cause granulomatous inflammation. ${ }^{[4, I I]}$ The most common causes of non-infectious GAp are foreign bodies, appendiceal diverticulitis, primary or metastatic appendiceal tumors, Crohn's disease, interval/delayed appendectomy due to perforation or plastron, chronic or recurrent appendicitis, and sarcoidosis. ${ }^{[4,7,11,12]}$ On the other hand, the most common causes of infectious GAp are Yersinia spp., Lycobacterium spp., Actinomyces spp., Schistosoma spp., Histoplasma spp., Candida spp., Aspergillus spp., Strongyloides spp., Campylobacter spp., Toxoplasma spp., Brucella spp., and other parasitic diseases. ${ }^{[3-6,13]}$ Eosinophilic granuloma that is characterized by granulomatous inflammation are generally considered to be an indirect indicator for parasitic infections, such as strongyloidiasis, schistosomiasis and enterobiasis. ${ }^{[4,13]}$ We think that it would be more appropriate to include eosinophilic granulomas into the infectious group. We were able to demonstrate that only 
Table I. Demographic and clinical parameters of 16 patients with granulomatous appendicitis

\begin{tabular}{|c|c|c|c|c|c|c|c|}
\hline Patient ID & Age & Sex & Familial TB history & Pulmonary TB & Extrapulmomary TB & PPD (mm) & ESR $(\mathrm{mm} / \mathrm{h})$ \\
\hline SC & 37 & $\mathrm{~F}$ & No & $(-)$ & $(-)$ & I & 31 \\
\hline $\mathrm{HC}$ & 23 & $M$ & No & $(-)$ & $(-)$ & 7 & 44 \\
\hline TE & 42 & $M$ & No & $(-)$ & $(-)$ & 2 & 2 \\
\hline OA & 29 & $M$ & No & $(-)$ & $(-)$ & 4 & 2 \\
\hline MK & 28 & M & No & $(-)$ & $(-)$ & 7 & 7 \\
\hline BC & 22 & M & No & $(-)$ & $(-)$ & 4 & 2 \\
\hline LP & 53 & $\mathrm{~F}$ & No & $(-)$ & $(-)$ & 2 & 26 \\
\hline BD & 53 & $F$ & No & $(-)$ & $(-)$ & 4 & 27 \\
\hline SK & 22 & $F$ & No & $(-)$ & $(-)$ & 10 & 36 \\
\hline SFE & 21 & $\mathrm{~F}$ & No & $(-)$ & $(-)$ & I & 10 \\
\hline SD & 33 & M & No & $(-)$ & $(-)$ & 10 & 14 \\
\hline VA & 70 & $M$ & NA & NA & NA & NA & NA \\
\hline ND & 26 & M & No & NA & NA & NA & NA \\
\hline OG & 32 & M & No & $(-)$ & $(-)$ & 3 & NA \\
\hline $\mathrm{HB}$ & 82 & $M$ & No & $(-)$ & $(-)$ & NA & NA \\
\hline RO & 24 & $\mathrm{~F}$ & No & $(-)$ & $(-)$ & I & 8 \\
\hline IGRA & & time PCR & EZN stain & App length (mm) & App diameter (mm) & Postop TB & Follow up (mo) \\
\hline$(-)$ & & $(-)$ & $(-)$ & 60 & I5 (Perf) & No & 125 \\
\hline$(-)$ & & $(-)$ & $(-)$ & 80 & 10 & No & 41 \\
\hline$(-)$ & & $(-)$ & $(-)$ & 80 & 5 (Perf) & No & 90 \\
\hline Indeterminate & & $(-)$ & $(-)$ & 90 & 15 & No & 40 \\
\hline$(-)$ & & $(+)$ & $(-)$ & 90 & 15 & No & 60 \\
\hline$(-)$ & & $(-)$ & $(-)$ & 75 & 15 & No & 65 \\
\hline$(-)$ & & $(-)$ & $(-)$ & 60 & 5 & No & 68 \\
\hline$(+)$ & & $(-)$ & $(-)$ & 70 & 6 & No & 115 \\
\hline$(-)$ & & $(-)$ & $(-)$ & 105 & 20 (Perf) & No & 58 \\
\hline$(+)$ & & $(-)$ & $(-)$ & 100 & 35 & No & 74 \\
\hline$(-)$ & & $(-)$ & $(-)$ & 80 & 4 & No & 65 \\
\hline NP & & $(-)$ & $(-)$ & 60 & 5 & NA & NA \\
\hline NP & & $(+)$ & $(-)$ & 50 & 7 & NA & NA \\
\hline NP & & $(-)$ & $(-)$ & 45 & 20 & No & 186 \\
\hline NP & & $(+)$ & $(-)$ & 55 & 8 & Dead & I \\
\hline$(-)$ & & $(-)$ & $(-)$ & 50 & 5 & No & 28 \\
\hline
\end{tabular}

TB: Tuberculosis; PPD: Tuberculosis skin test; F: Female; M: Male; NA: Non-available; (-): Negative; (+): Positive; NP: No-performed; EZN: Ehrlich-Ziehl-Neelsen; IGRA: Interferon-Gamma (IFN- $\gamma$ ) Release Assay; PCR: Polymerase chain reaction; ESR: Erythrocyte sedimentation rate; Perf: Perforation; App: Appendix.

one of the patients presented in this study was non-infectious GAp (Crohn's disease). In another patient, although tumor infiltration was detected histopathologically in the serosal surface of appendix vermiformis, clinical and molecular biological results were consistent with infectious GAp (TB).

There are no specific intraoperative macroscopic findings suggestion of GAp in patients who underwent surgery for AAp. Therefore, histopathological evaluation of appendecto- my specimens is the first step for both diagnosis and differential diagnosis of GAp. Even if no specific factors have been identified during histopathological examination (idiopathic), the morphological structure of granulomas mentioned above may provide important clues for possible causes. The following types of inflammation can be seen in appendectomy specimens of patients with GAp: necrotizing granulomas (Mycobacterium tuberculosis, Yersinia spp.), non-necrotizing granulomas (Crohn's disease, sarcoidosis, Schistosoma spp.), 
suppurative granulomas (Actinomyces spp., non-tuberculous mycobacteria) and foreign body type granuloma. ${ }^{[4,8]}$ In the study of AbdullGaffar et al.,, ${ }^{[4]}$ non-necrotizing and necrotizing GAp rates were $15.4 \%$ and $7.7 \%$, respectively. However, in our study, these rates were $43.7 \%(n=7)$ and $56 \%(n=9)$, respectively.

After the histopathological findings were consistent with GAp, personal history (travel history, fever, bloody or normal diarrhea, weight loss, fatigue, immunosuppressive drug use, chronic pulmonary disease, socioeconomic status) and familial TB history should be investigated for further diagnosis or differential diagnosis of GAp. Although they vary according to geographical regions, Crohn's disease, Yersinia spp. and Mycobacterium spp. are the first three common diseases that need to be addressed in the differential diagnosis of GAp. Although some authors continue to argue otherwise, there is no underlying cause in the majority of patients, which is defined as idiopathic GAp. ${ }^{[3]}$

AbdullGaffar et al. ${ }^{[4]}$ have claimed that the factors causing secondary GAp are geographically distributed. Crohn's disease and Yersinia spp. are the most common causes of GAp in the west, while TB and many parasitic infestations are among the most common causes of GAp in tropical and subtropical regions. ${ }^{[4,14]}$ Turkey has a transition position between East and West regarding socioeconomic level, sanitation, and industrialization. ${ }^{[15]}$ Turkey bears features of both communities in terms of incidence rates of some diseases, TB and inflammatory bowel disease (Crohn's disease) are the most typical prototypes of this situation. ${ }^{[15,16]}$ Therefore, it is necessary to consider the features of both communities in the differential diagnosis of GAp, especially in terms of TB and Crohn's disease.

Intestinal TB is a particular diagnostic challenge due to nonspecific clinical and radiological findings, difficulty in collecting good-quality specimen, and low performance of the laboratory analyses in intestinal samples, which mostly developed for the diagnosis of pulmonary TB. Kapoor and Sharma ${ }^{[17]}$ showed that almost half of the patients with intestinal TB were undiagnosed. Additionally, intestinal TB can mimic other digestive tract diseases, such as Crohn's disease and malignancy. Cheng et al. ${ }^{[18]}$ reported that $80 \%$ of the cases with intestinal TB were misdiagnosed as inflammatory bowel diseases, ileus, appendicitis, or other intestinal diseases. Therefore, a high degree of suspicion and systematic use of TB tests are essential for a precise diagnosis of the disease. The diagnostic dilemma in the patients presented in this study was particularly related to TB and Crohn's disease.

Specific diagnostic tests for appendicular TB are histopathological examination, microscopic examination for AFB, tissue culture, tissue PCR, PPD skin test, and IGRAs. Though these diagnostic methods have been extensively studied in the pulmonary TB, fewer data exist regarding their diagnostic performances in intestinal TB. AFB microscopy is the simplest and fastest method; however, its sensitivity is very low even for the pulmonary samples at optimal quality. In the intestinal $T B$, the sensitivity of this method was reported to be around $30 \%{ }^{[19,20]}$ Tissue TB culture is the gold standard for the diagnosis of intestinal TB, it requires a long time (six weeks) to results, and the sensitivity of this method is between $20 \%$ and $50 \% .{ }^{[21,22]}$ Recently-developed PCR kits have advanced the diagnosis of TB. For example, a TB PCR kit -Xpert MTB/RIF (Xpert; Cepheid Inc., US)- was reported to correctly detect all smear-positive pulmonary and extrapulmonary samples (sensitivity 100\%) within two hours. ${ }^{[23]}$ Regarding the intestinal TB, GeneXpert MTB/RIF kit was found positive in $20 \%$ of the stool samples, and its sensitivity and specificity ratios were detected as $39.1 \%$ and $85.7 \%$, respectively, in intestinal mucosal biopsy specimens. ${ }^{[24]}$ However, very limited data exist on this issue, and more studies are required to understand better the diagnostic performance of such last generation TB PCR kits in gastrointestinal TB. In recent years, IGRA tests have brought significant advantages in the clinical diagnosis of TB. A positive IGRA test indicates previous or ongoing exposure to $M$. tuberculosis. In a retrospective evaluation of 109 patients with intestinal TB, the IGRA test gave a positive result for $75.2 \%$ of the patients. ${ }^{[25]} \mathrm{Ng}$ et al. ${ }^{[26]}$ stated that sensitivity and specificity of the IGRA test for intestinal TB were $81 \%$ and $85 \%$, respectively. Tissue culture was not studied in any of the patients presented here because TB was not considered among the preoperative differential diagnoses. In the present study, blood IGRA and paraffin tissues blocks PCR positivity rates were $16.7 \%$ and $18.75 \%$, respectively.

Anamnesis, colonoscopy, anti-saccharomyces cerevisiae antibody and perinuclear anti-neutrophil cytoplasmic antibody tests can be used in the differential diagnosis of cases with histopathological findings indicating Crohn's disease. Although primary (isolated) appendiceal

Crohn's disease is detected in $0.2-4.9 \%$ of all appendectomy specimens, appendiceal involvement is detected in around $24 \%$ of patients treated for ileocecal Crohn's disease. . $^{[3,6,11,27]}$ Although post-appendectomy complications (abscess, fistula) are very rare in patients with primary appendiceal Crohn's disease, these complications develop in $15-20 \%$ of patients with ileocecal Crohn's disease. ${ }^{[6,27]}$ In addition, $5-10 \%$ of patients confirmed to have idiopathic GAp developed gastrointestinal Crohn's disease 3-48 months after appendectomy. $[3,5,7]$ For these reasons, many authors suggest that patients with GAp should be followed closely because of the potential for Crohn's disease. ${ }^{[6,27]}$ Only one patient presented in this study developed an early postoperative fistula and confirmed Crohn's disease. No complications related to Crohn's disease developed in the long-term follow-up of the remaining 14 patients with GAp.

In conclusion, it is not easy to distinguish the causes of GAP with histopathological examination. In such cases, clinical findings, tissue PCR, IGRA, and tissue culture can be used in the 
differential diagnosis of GAp. None of the patients showed symptoms of TB or Crohn's disease during the follow-up period, suggesting that idiopathic GAp rates were higher than expected. Finally, all appendectomy specimens should be sent to the laboratory for histopathological evaluation and patients should be advised to come to the outpatient clinic with the pathology reports. Thus, in patients whose pathology reports are compatible with GAP, PCR and IGRA analyses can be performed, and systemic diagnosis should investigate as an early term as possible.

Ethics Committee Approval: Approved by the local ethics committee.

\section{Peer-review: Internally peer-reviewed.}

Authorship Contributions: Concept: S.A.; Design: S.A., C.K., K.B.S.; Materials: K.B.S., C.K., E.Ş, Y.Y., Y.B.; Data: K.B.S., C.K.; Analysis: S.A.; Literature search: S.A., C.K.; Writing: S.A.; Critical revision: S.A., Y.Y., Y.B.

Conflict of Interest: None declared.

Financial Disclosure: The authors declared that this study has received no financial support.

\section{REFERENCES}

1. Akbulut S, Tas M, Sogutcu N, Arikanoglu Z, Basbug M, Ulku A, et al. Unusual histopathological findings in appendectomy specimens: a retrospective analysis and literature review. World J Gastroenterol 2011;17:1961-70. [CrossRef]

2. Yilmaz M, Akbulut S, Kutluturk K, Sahin N, Arabaci E, Ara C, et al. Unusual histopathological findings in appendectomy specimens from patients with suspected acute appendicitis. World J Gastroenterol 2013;19:4015-22. [CrossRef]

3. Pal K. Granulomatous appendicitis in children: a single institutional experience. Afr J Paediatr Surg 2014;11:26-31. [CrossRef]

4. AbdullGaffar B. Granulomatous diseases and granulomas of the appendix. Int J Surg Pathol 2010;18:14-20. [CrossRef]

5. Lamps LW, Madhusudhan KT, Greenson JK, Pierce RH, Massoll NA, Chiles MC, et al. The role of Yersinia enterocolitica and Yersinia pseudotuberculosis in granulomatous appendicitis: a histologic and molecular study. Am J Surg Pathol 2001;25:508-15. [CrossRef]

6. Tucker ON, Healy V, Jeffers M, Keane FB. Granulomatous appendicitis. Surgeon 2003;1:286-9. [CrossRef]

7. Gu J, Allan C. Idiopathic granulomatous appendicitis: a report of three consecutive cases. ANZ J Surg 2010;80:201. [CrossRef]

8. Shah KK, Pritt BS, Alexander MP. Histopathologic review of granulomatous inflammation. J Clin Tuberc Other Mycobact Dis 2017;7:1-12.

9. Mazurek GH, Jereb J, Vernon A, LoBue P, Goldberg S, Castro K; IGRA Expert Committee; Centers for Disease Control and Prevention (CDC). Updated guidelines for using Interferon Gamma Release Assays to detect Mycobacterium tuberculosis infection - United States, 2010. MMWR Recomm Rep 2010;59:1-25.
10. Meyerding EV, Bertram HF. Nonspecific granulomatous inflammation (Crohn's disease) of the appendix; a case report. Surgery 1953;34:891-4.

11. Yayla D, Alpman BN, Dolek Y. Granulomatous appendicitis in a 12-yearold boy. J Pediatr Surg 2010;45:e27-9. [CrossRef]

12. Guo G, Greenson JK. Histopathology of interval (delayed) appendectomy specimens: strong association with granulomatous and xanthogranulomatous appendicitis. Am J Surg Pathol 2003;27:1147-51. [CrossRef]

13. Rha B, Kelly DR, Shimamura M. Eosinophilic Appendicitis Attributable to Strongyloides Infection in a Pediatric Renal Transplant Patient. J Pediatric Infect Dis Soc 2013;2:274-7. [CrossRef]

14. Wu H, Fuller MY, Pogoriler J. Granulomatous Appendicitis in the Pediatric Population. Pediatr Dev Pathol 2020;23:215-21. [CrossRef]

15. Can G, Poşul E, Yılmaz B, Can H, Korkmaz U, Ermiş F, et al. Epidemiologic features of inflammatory bowel disease in Western Blacksea region of Turkey for the last 10 years: retrospective cohort study. Korean J Intern Med 2019;34:519-29. [CrossRef]

16. Pala K, Gerçek H, Taş TA, Çakir R, Özgüç S, Yildiz T. 30 Years Retrospective Review of Tuberculosis Cases in a Tuberculosis Dispensary in Bursa/Nilufer, Turkey (1985-2014): Changes of Epidemics. Mediterr J Hematol Infect Dis 2016;8:e2016059. [CrossRef]

17. Kapoor VK, Sharma LK. Abdominal tuberculosis. Br J Surg 1988;75:2-3. [CrossRef]

18. Cheng W, Zhang S, Li Y, Wang J, Li J. Intestinal tuberculosis: clinicopathological profile and the importance of a high degree of suspicion. Trop Med Int Health 2019;24:81-90. [CrossRef]

19. Rana S, Farooqui MR, Rana S, Anees A, Ahmad Z, Jairajpuri ZS. The role of laboratory investigations in evaluating abdominal tuberculosis. J Family Community Med 2015;22:152-7. [CrossRef]

20. Cho JK, Choi YM, Lee SS, Park HK, Cha RR, Kim WS, et al. Clinical features and outcomes of abdominal tuberculosis in southeastern Korea: 12 years of experience. BMC Infect Dis 2018;18:699. [CrossRef]

21. Patel B, Yagnik VD. Clinical and laboratory features of intestinal tuberculosis. Clin Exp Gastroenterol 2018;11:97-103. [CrossRef]

22. Nayagam JS, Mullender C, Cosgrove C, Poullis A. Abdominal tuberculosis: Diagnosis and demographics, a 10 -year retrospective review from a single centre. World J Clin Cases 2016;4:207-12. [CrossRef]

23. Ozkutuk N, Surucüoglu S. Evaluation of the Xpert MTB/RIF assay for the diagnosis of pulmonary and extrapulmonary tuberculosis in an intermediate-prevalence setting. [Article in Turkish]. Mikrobiyol Bul 2014;48:223-2. [CrossRef]

24. Talib A, Bhatty S, Mehmood K, Naim H, Haider I, Lal H, et al. GeneXpert in stool: Diagnostic yield in Intestinal Tuberculosis. J Clin Tuberc Other Mycobact Dis 2019;17:100131. [CrossRef]

25. Jung HJ, Kim YH, Kim YS, Jeong SY, Park SW, Seo JY, et al. Differences in Clinical Manifestations according to the Positivity of Interferon- $\gamma$ Assay in Patients with Intestinal Tuberculosis. Gut Liver 2016;10:649-52.

26. Ng SC, Hirai HW, Tsoi KK, Wong SH, Chan FK, Sung JJ, et al. Systematic review with meta-analysis: accuracy of interferon-gamma releasing assay and anti-Saccharomyces cerevisiae antibody in differentiating intestinal tuberculosis from Crohn's disease in Asians. J Gastroenterol Hepatol 2014;29:1664-70. [CrossRef]

27. Mizushima T, Ito T, Mizuno H, Udatsu Y, Miyazaki Y, Imakita M, et al. Idiopathic granulomatous appendicitis treated surgically with long-term follow-up: report of a case. Surg Today 2007;37:690-3. [CrossRef] 


\section{ORİJINAL ÇALIŞMA - ÖZET}

\section{Granülomatöz apandisitin ayırıcı tanısı: On altı olgunun geriye dönük analizi}

\section{Dr. Sami Akbulut, ${ }^{1}$ Dr. Cemalettin Koç, ${ }^{1}$ Dr. Kemal Barış Sarıcı, ${ }^{1}$ Dr. Emine Şamdancı, ${ }^{2}$} Dr. Yusuf Yakupoğulları, ${ }^{3}$ Dr. Yaşar Bayındır ${ }^{4}$

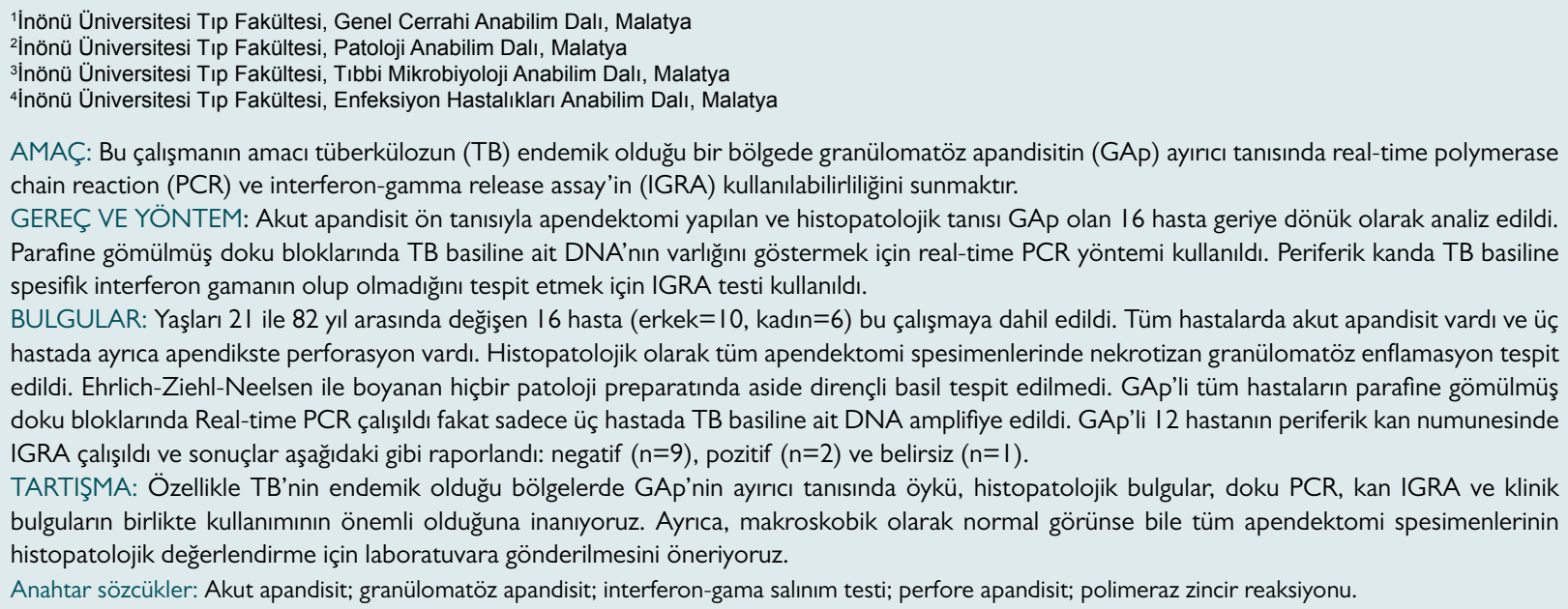

AMAÇ: Bu çalışmanın amacı tüberkülozun (TB) endemik olduğu bir bölgede granülomatöz apandisitin (GAP) ayırıcı tanısında real-time polymerase chain reaction (PCR) ve interferon-gamma release assay'in (IGRA) kullanılabilirliliğini sunmaktır.

GEREÇ VE YÖNTEM: Akut apandisit ön tanısıyla apendektomi yapılan ve histopatolojik tanısı GAp olan 16 hasta geriye dönük olarak analiz edildi. Parafine gömülmüş doku bloklarında TB basiline ait DNA'nın varlığını göstermek için real-time PCR yöntemi kullanıldı. Periferik kanda TB basiline spesifik interferon gamanın olup olmadığını tespit etmek için IGRA testi kullanıldı.

BULGULAR: Yaşları 21 ile 82 yıl arasında değişen 16 hasta (erkek=10, kadın=6) bu çalışmaya dahil edildi. Tüm hastalarda akut apandisit vardı ve üç hastada ayrıca apendikste perforasyon vardı. Histopatolojik olarak tüm apendektomi spesimenlerinde nekrotizan granülomatöz enflamasyon tespit edildi. Ehrlich-Ziehl-Neelsen ile boyanan hiçbir patoloji preparatında aside dirençli basil tespit edilmedi. GAp’li tüm hastaların parafine gömülmüş doku bloklarında Real-time PCR çalışıldı fakat sadece üç hastada TB basiline ait DNA amplifiye edildi. GAp'li I2 hastanın periferik kan numunesinde IGRA çalışıldı ve sonuçlar aşağıdaki gibi raporlandı: negatif $(n=9)$, pozitif $(n=2)$ ve belirsiz $(n=1)$.

TARTIŞMA: Özellikle TB'nin endemik olduğu bölgelerde GAp'nin ayırıcı tanısında öykü, histopatolojik bulgular, doku PCR, kan IGRA ve klinik bulguların birlikte kullanımının önemli olduğuna inanıyoruz. Ayrıca, makroskobik olarak normal görünse bile tüm apendektomi spesimenlerinin histopatolojik değerlendirme için laboratuvara gönderilmesini öneriyoruz.

Anahtar sözcükler: Akut apandisit; granülomatöz apandisit; interferon-gama salınım testi; perfore apandisit; polimeraz zincir reaksiyonu.

Ulus Travma Acil Cerrahi Derg 2021;27(2):214-221 doi: 10.14744/tjtes.2020.98582 